\title{
The Potential to Secure a Fair Trial Through Evidence Exclusion: A Taiwanese Perspective
}

\author{
Yu-Hsiung Lin, Shih-Fan Wang, Chung-Yen Chen, Tsai-Chen Tsai \\ and Chiou-Ming Tsai
}

\begin{abstract}
Taiwan, as one of the jurisdictions comprising the so-called "fourth wave of democratization," fundamentally altered its criminal justice system over the course of just decades. This was particularly true with respect to the rule of law and the procedural law around the exclusion of evidence. For example, although illegally obtained, or "tainted" evidence may be crucial in the search for the truth, it is to be excluded if it was obtained under certain circumstances, including torture or coercion. The legal theory behind this area of Taiwanese law is grounded in the common law criminal justice system, although Taiwan has developed its own procedures and remedies. How illegally obtained evidence is excluded in Taiwanese criminal procedure is discussed, as is the melding of the Thai approach with its theoretical basis in Anglo-US criminal procedure. Both practical and theoretical perspectives are explored and the gaps between the formation of legislation and its enactment into judicial practice are addressed.
\end{abstract}

\footnotetext{
Y.-H. Lin $(\square)$

National Taiwan University, Taipei, Taiwan

e-mail: yslmy41@yahoo.com.tw

S.-F. Wang

National Taipei University, New Taipei City, Taiwan

e-mail: shihfan.wang@gmail.com

C.-Y. Chen

University of Tübingen, Tübingen, Germany

e-mail: thechosenjoe@gmail.com

T.-C. Tsai

Shihlin District Court, Taipei, Taiwan

e-mail: alberts@mail.moj.gov.tw

C.-M. Tsai

Department of International and Cross-Strait Legal Affairs, Ministry of Justice, Taipei,

Taiwan

e-mail: grace@mail.judicial.gov.tw

(C) The Editor(s) (if applicable) and The Author(s) 2019

S. Gless and T. Richter (eds.), Do Exclusionary Rules Ensure a Fair Trial?

Ius Gentium: Comparative Perspectives on Law and Justice 74,

https://doi.org/10.1007/978-3-030-12520-2_5
} 


\section{Introduction}

Taiwan's legal system is committed to the rule of law as well as to respect for human rights. It bridges the legacy of Chinese law from the penultimate century with modern legal rules. With regard to the criminal justice system, and more particularly with regard to fact-finding in criminal proceedings, Taiwan's Code of Criminal Procedure (CCP: 刑事訴訟法 ${ }^{1}$ ) obliges the authorities to search for the truth, while protecting human rights at the same time. ${ }^{2}$ These principles also translate into the making of exclusionary rules: While all authorities are bound to search for the truth in a criminal investigation (Art. 2 of the $\mathrm{CCP}^{3}$ ), they must not put the search for truth above all other considerations. ${ }^{4}$ The Taiwanese criminal justice system sets clear limits with the provisions of the CCP. ${ }^{5}$ Therefore, criminal proceedings may not be initiated and punishment may not be imposed other than in conformity with the procedure specified in this Code or in other laws.

If evidence is obtained in violation of procedural rules, the question thus arises as to whether such evidence can be excluded from the fact-finding process. ${ }^{6}$ From the point of view of courts, according to Taiwanese law exclusionary rules serve different purposes: (a) protecting human dignity of the defendant and his status as a party, (b) safeguarding the liberty of mental decision and mental activities of the defendant, and (c) deterring illegal investigatory activity based on the principle of due process. $^{7}$ The lawmaker has not addressed this problem with one general provision, but provided several key statutes (Arts. 156 para. $1,{ }^{8} 158-2^{9}$ and $158-4^{10}$ of the $\mathrm{CCP}$ ) that provide for an exclusion of certain evidence, which is obtained in

\footnotetext{
${ }^{1}$ Available online at $<$ http://law.moj.gov.tw/LawClass/LawAll.aspx ?PCode=C0010001 $>$, officially translated as The Code of Criminal Procedure of 28 July 1928 (Status as of 12 December 2007), available online at <http://law.moj.gov.tw/Eng/LawClass/LawAll.aspx?PCode=C0010001>, accessed 21 November 2018.

${ }^{2}$ LIN Yu-Hsiung, 2013 (I) at 7-10; ZHU Shi-Yan, 2015 at 8.

${ }^{3}$ See Annex.

4"Keine Wahrheit um jeden Preis. "In Taiwanese practice this is a general consensus, e.g. the interpretation No. 130 of the Judicial Yuan (22 December 1995) states: Although the state has the goal of finding out the truth in criminal justice proceedings, it does not mean that the state can attain this goal by whatever means available (國家爲達成刑事司法究明案件真象之目的, 非謂 即可訴諸任何手段).

${ }^{5}$ Art. 1 of the CCP clearly states that all criminal investigations and criminal prosecutions are bound by the rule of law.

${ }^{6}$ E.g. Supreme Court precedent 93 taishangzih No. 664 (最高法院 94 年台上字第 664 號判例) and Supreme Court decision 94 taishangzih No. 275 (最高法院 94 年度台上字第 275 號判決); WANG Jaw-Perng, 2011 at 8-10.

${ }^{7}$ See below 3.2 .

${ }^{8}$ See Annex.

${ }^{9}$ See Annex.

${ }^{10}$ See Annex.
} 
violation of a legal requirement. These specific provisions often balance the interests of criminal justice and the need for coherent fact-finding with the protection of individual rights. ${ }^{11}$

\section{General Framework for Establishing Facts in Criminal Proceedings}

Taiwan's CCP was enacted in $1928 .^{12}$ At first, it was published and implemented in mainland China as first Code of Criminal Procedure in the Republic of China (ROC). After World War II and further struggle with the Communist Party of China, the government of the Republic of China relocated to the island of Taiwan which, at that moment, was not longer colonized by Japan. The Republic of China brought its legal system to Taiwan, including the CCP, whereas all former laws were abolished in mainland China after proclamation of the People's Republic of China (PRC).

\subsection{Legal Framework and Relevant Actors}

\subsubsection{General Rules}

The commitment that criminal proceedings primarily serve the ascertainment of truth is reflected in various provisions of the CCP: First of all Art. 2 para. 1 of the CCP obligates public officials investigating a criminal case to give equal attention to circumstances both favorable and unfavorable to a defendant. This means that the investigation is conducted open-mindedly and authorities are bound to objectivity, in order to discover the truth and thus not wronging innocent individuals or

\footnotetext{
${ }^{11}$ In the law-materials the following factors are formulated: (a) the circumstances of the violation of the procedure prescribed by the law: must be taken into account of whether there were difficulties in collecting evidence lawfully; (b) the subjective intentions of the official: referring to whether the official knows that his conduct is unlawful; (c) the nature and the severity of the right that was infringed: referring to the circumstances of the infringement; (d) the risk and harm of the crime: referring to the nature of the crime and its circumstances; (e) the deterrence effect of excluding such evidence; (f) whether it is unavoidable that officials will discover such evidence using procedure prescribed by law: the standard may be loosened if such evidence can be acquired through normal proceedings; and (g) the effect of the unlawful evidence has on the defense of the accused. See also: LIN Yu-Hsiung, 2013 (I) at 593 et seq.

${ }^{12}$ About the detailed development see CHEN Yu-Jie, 2011 at 713-28; WANG Jaw-Perng, 2011 at 19-21.
} 
condoning offenders. ${ }^{13}$ In that respect, Taiwan's Criminal justice system is more based on the inquisitorial model, as found in Continental Europe, than the adversarial system, as found in England or the United States.

\subsubsection{Law Determining Duties in Criminal Investigations}

In Taiwan, prosecutors and police officers act as investigating authorities. As soon as an investigative authority learns about an alleged crime, it can ex officio start investigating. Investigating authorities are obligated to actively investigate the facts of an alleged crime that comes to their knowledge as a result of a complaint, report, voluntary surrender or other reason. ${ }^{14}$ Finally, if a case is prosecuted, the court must actively - ex officio - investigate all the circumstances relevant to the assessment of the criminal act and the defendant. ${ }^{15}$ For the court, there is not only an ex officio obligation to discover the solid truth, but also, by legal requirements, to prove that the defendant indeed committed a crime if it is to bring in a guilty verdict. Guilt is proven if the evidence presented before a court ${ }^{16}$ shows that the defendant is guilty beyond a reasonable doubt. ${ }^{17}$

Although confessions of defendants are regarded as evidence in Taiwan's criminal procedure, the law specifically stipulates that confessions cannot be the only reference for a guilty verdict. As stipulated in Art. 156 para. 2 of the CCP: a "[c]onfession of a defendant, or a co-offender, shall not be used as the sole basis of conviction and other necessary evidence shall still be investigated to see if the confession is consistent with facts." The statute shall prevent the prosecution authorities from overly relying on confessions of defendants or accomplices. ${ }^{18}$

In fact, Taiwan's CCP has seen many strict regulations on the use of confessions, which shows a certain caution in this respect. ${ }^{19}$ Under the heavy judiciary burden of recent years, however, Taiwan's criminal justice system had no other choice but to introduce plea-bargaining in 2004. ${ }^{20}$ But it refrained from fact bargaining: The court

\footnotetext{
${ }^{13}$ Nonetheless, in 2004 we have introduced the bargaining process, which is regulated from Arts. 455-2 to 455-11 in the CCP. The expert criticize that establishment of plea-bargaining does not base on truth, but on the admitted facts, see e.g. LIN Yu-Hsiung, 2013 (II) at 289-90.

${ }^{14}$ See Arts. 228 para. 1, 230 para. 2, 231 para. 2 of the CCP.

${ }^{15}$ Art. 163 para. 2 of the CCP.

${ }^{16}$ The exception is so-called Summary Procedure in Arts. 449 of the CCP (簡易程序): If a defendant's confession in the investigation process or other existing evidence is sufficient for the court of first instance to determine a defendant's offense, a sentence may be pronounced through summary judgment without common trial procedure upon request by the prosecutor; provided that the defendant shall be questioned before sentencing if necessary.

${ }^{17}$ See Arts. 154 para. 2, 163 para. 2 of the CCP.

${ }^{18}$ ZHU Shi-Yan, 2015 at 179.

${ }^{19}$ See with more details in 3 Limitations of Fact-Finding in Criminal Proceedings.

${ }^{20}$ Arts. 455-2 to 455-11 of the CCP. See LIN Yu-Hsiung, 2013 (II) at 254-55; ZHU Shi-Yan, 2015 at $577-79$.
} 
may not pronounce a bargaining judgment, when facts established by the court are different from the facts agreed on during the bargaining process. Nonetheless, inevitably questions about "confessions for bargaining" or "fact trading" have been raised. Scholars fear that justice will be for sale ("Handel mit Gerechtigkeit"). ${ }^{21}$

\subsubsection{Laws Securing a Fair Trial}

Despite the fact that prosecution authorities have the obligation to search for the truth and to investigate all circumstances of a case, both unfavorable and favorable for the defendant, it is naturally difficult for a prosecutor to always stay impartial and detached while collecting evidence. Therefore, the defendant and the defense counsel have rights of their own in order to ensure a fair trial. Taiwan's CCP grants defendants various procedural rights, placing an overall limitation on the powers at the disposal of the investigating authorities.

In particular, the defendant enjoys the following procedural rights, any violation of which may result in an exclusionary effect according Arts. 158-2 or 158-4 of the CCP:

- The right to counsel according to Art. 27 para. 1 and Art. 34 para. 1 of the CCP

- The right of the defendant to be properly informed according to Art. 95 para. 1 of the $\mathrm{CCP}$

- Audio and, eventually, video recording of the interrogation of the defendant must be in its entirety according to Art. 100-1 para. 1 of the CCP.

\subsubsection{Laws Balancing the Search for the Truth and Infringements of Individual Rights}

If the rights of a defendant were violated during criminal proceedings, the defendant may ask for the exclusion of evidence based on Art. 158-4 of the CCP. But the question of the burden of proof in such an instance remains unresolved. There is no general provision setting out the burden of proof in the event of an authorities' violation of rules. Only in the particular case of a defendant pleading that a confession was coerced is burden on the authorities to prove that the confession was in fact made voluntarily. ${ }^{22}$ If the defendant claims that a confession was extracted by improper means, the confession shall be investigated prior other evidence being investigated by the court that decides on the merit of the (public) trial. If such a confession is presented by the public prosecutor, the court shall order the public prosecutor to indicate the method of proving that the confession has been given voluntarily (see. Art. 156 para. 3 of the $\mathrm{CCP}^{23}$ ). It is noteworthy (a) that the

\footnotetext{
${ }^{21}$ LIN Yu-Hsiung, 2013 (II) at 287.

${ }^{22}$ Supreme Court decision 94 taishangzih No. 275 (最高法院 94 年度台上字第 275 號制決).

${ }^{23}$ See Annex.
} 
evidence that is possibly to be excluded is then made public and (b) that in court practice, the responsibility to prove whether the legal procedures are violated or not has always been bestowed on the state institutions. If the state institution is not able to prove that the defendant's rights are not damaged, the Supreme Court (最高法 院) clearly pointed out that the defendant's right will be seen as damaged and the confession must be excluded. ${ }^{24}$

Additionally, in order to document that a defendant's interrogation is conducted according to the rules and a possible confession is based on free-will, Art. 100-1 ${ }^{25}$ of the CCP provides that the whole proceeding of examining the defendant shall be recorded without interruption in audio, and also, if necessary, in video. The effect of a violation is then provided for in Art. 100-1 para. 2. If there is an inconsistency between the content of the record and that of the audio or video record regarding the statements made by the defendant, any such portion of the statement shall not be used as evidence. Of course, if the criminal investigation authority informally talks to the defendant about the case and press for a confession of the crime prior to the "official" recording, the purposes of all these specific measures for the interrogation are rendered void and the safeguards can be circumvented.

\subsubsection{Establishing Facts-Stages and Rules}

The handing of a case in the Taiwanese criminal procedure can be divided into four stages: the police investigation stage, the prosecutor investigation stage, the court trial stage and, if a guilty verdict is rendered, the enforcement of a judgment.

The police and prosecutors' investigations are so called pre-trial investigations. According to the Taiwanese model, prosecutors are in charge of supervising the police, who do the main body of work during investigations. ${ }^{26}$ After the police have finished their investigations, the case is handed over to the prosecution service. The competent prosecutor decides whether the requirements for an indictment are met or not. If a case is prosecuted, it will be referred to the court and, until this stage, the potential for evidence to be excluded plays a role. Generally, a criminal case is run by the normal three-tiered judicial system, i.e. prosecuted at a District Court in first instance, the High Court, and the Supreme Court. If a conviction is final, the prosecutor of the competent court shall perform the execution of the judgement.

Furthermore, due to the requirement for courts to seek the truth (see Art. 163 para. 2 of the CCP), people often state that, "judges are doing God's work." (法

\footnotetext{
${ }^{24}$ See Supreme Court decision 94 taishangzih No. 275 (最高法院 94 年度台上字第 275 號判決). The literature consistently stands for the decision, e.g. LIN Yu-Hsiung, 2013 (I) at 202; ZHU Shi-Yan, 2015 at 178.

${ }^{25}$ See Annex.

${ }^{26}$ See Art. 230 para. 1 of the CCP.
} 
官在做神的工作). ${ }^{27}$ Prior to amendments on February 8, 2002, Art. 163 of the CCP stipulated that due to the necessity of truth finding, courts "shall" ex officio investigate evidence. Although subsequently influenced by the adversarial system of US-American criminal procedure, the code still states " $[t]$ he court may, for the purpose of discovering the truth, ex officio investigat[e] evidence" (Art. 163 para. 2 of the $\mathrm{CCP}$ ). The stipulation that "for the purpose of maintaining justice or discovering facts that are critical to the interest of the defendant, the court shall ex officio investigate evidence" reflects the importance of fact-finding in Taiwan's criminal justice system.

\subsubsection{Establishing Facts-Actors and Accountability}

In Taiwan's CCP, during the stage of investigation the prosecutor is in charge of fact-finding. If a member of the prosecution does not fulfill the duty and eventually causes a wrongful sentence, the person will not be subject to a special procedure, but—in theory—faces a prosecution for “Abuse of Prosecution” (“濫權追訴罪”), according to Art. 125 of the Criminal Code of the Republic of China (CCRC). ${ }^{28}$

Defendants are considered to be a subject rather than an object of criminal procedure in the Taiwanese criminal justice system. Among other entitlements, defendants are protected by the presumption of innocence ${ }^{29}$ and the privilege against self-incrimination (Art. 95 para. 1 CCP; Art. 14 para. 3 (g) of ICCPR).

Furthermore, defendants have a right to assistance by a defense attorney (see Arts. 27 and 34 of the CCP). A defense attorney, in theory, plays an important role in Taiwan's CCP and should, in a situation of equality of arms, make use of defense rights to safeguard the defendant's interests. In practice, however, compared to the power of the prosecution authorities, there still appears to be a lot of room for improvement to empower defense lawyers in Taiwan ${ }^{30}$ if the goal is ultimately to reach an equality of arms.

\footnotetext{
${ }^{27}$ Supreme Court decision 104 taikangzih No. 766 (最高法院 104 年度台抗字第 766 號裁定): “the judge is also a person, not God, of course he inevitably does something wrong." (法官也是 人, 不是神, 當然難免絕對無錯).

${ }^{28} \mathrm{See}$ Annex. The text is available online at <http://law.moj.gov.tw/LawClass/LawContent.aspx? PCODE $=\mathrm{C} 0000001>$, officially translated as Criminal Code of the Republic of China of 1 January 1925 (Status as of 13 June 2018), available online at <http://law.moj.gov.tw/Eng/LawClass/ LawContent.aspx?PCODE=C000001>, accessed 21 November 2018.

${ }^{29}$ See Art. 154 para. 1 of the CCP.

${ }^{30}$ See WANG Jaw-Perng, 2011 at 15-18, especially at 17, who states: "Unfortunately, in some police stations, the accused's right to counsel means nothing more than the attorney may be present during interrogations. Even if the accused's attorney appears at the police station, some do not allow the attorney to speak with the accused. They sometimes ask the attorney to sit far behind the table at which they conduct interrogations. The major function of an attorney at the police station is not to consult the accused, but rather to watch for torture or other improper actions by the police."
} 


\subsection{Social Relevance of Truth and Individual Rights in Criminal Trials}

\subsubsection{Relevance of Determining the Truth}

In criminal proceedings, striking a balance between the search for truth and the protection of civil liberties (particularly those of the defendant) has been a longstanding and difficult issue. From the perspective of the Taiwanese CCP, discovering the truth has always been an extremely important value. Fortunately, during the last decades, compliance with the legal requirements for obtaining evidence has generally improved in Taiwan, which could make for balance, at least on the surface; if a violation of such procedural requirements takes place, criminal defense attorneys today advocate for the exclusion of illegally evidence. ${ }^{31}$ However, such pursuits by defense lawyers still occasionally draw public criticism, since the search for truth is held in much higher regard than the protection of individual rights (particularly those of the defendant).

Due to tradition, in the eyes of the public a confession by a defendant is still one of the most important proofs of guilt. Aside from very few exceptions, in practice, if a defendant confesses a crime, judges will not be open-minded, but handle proceedings with prejudice against the defendant. The existence of a confession directly affects how proceedings are conducted (such as whether to start a cross-examination or a more onerous investigation for evidence, etc.) and how they ought to be concluded (such as whether to proceed with plea bargaining procedures and quickly terminate legal proceedings).

\subsubsection{Presentation of "Facts", "Fact-Finding" and/or "Truth" to the Public}

Taiwan's public has considerable interest in criminal cases, which are featured in daily press and other media on a regular basis.

However, to ensure authenticity, while at the same time protecting the rights of the defendant and other stakeholders, Art. 245 para. 1 of the $\mathrm{CCP}^{32}$ states that the investigation shall not be public. Para. 3 of that provision ${ }^{33}$ makes further specifications. The provisions delineated in Art. 132 para. in CCRC provide the legal basis for the penal sanctioning of any investigators for willful or negligent

\footnotetext{
${ }^{31}$ WANG Jaw-Perng, 2011 at 19-21.

${ }^{32}$ See Annex.

${ }^{33}$ See Annex.
} 
misconduct leading to the leaking of investigation secrets. Persons restricted from coming into contact with or having knowledge of investigation secrets include not only any members of the public, but also the defendants themselves as well as the legal representatives of the defendant. According to Art. 33 of the CCP, the preceding parties are prohibited from examining the investigation case files or exhibits and making copies or taking photographs of the investigation case files or exhibits. ${ }^{34}$ The above applies regardless of whether the defendant has been placed under detention at the time of the investigation. ${ }^{35}$

Nevertheless, even when taking into account the strictness of the aforementioned rules on investigation conduct, and the understandable difficulties which lie in the preservation of investigation secrets due to media involvement, the majority of reported violations against Taiwanese prosecutors' offices are for misconduct resulting in the leakage of investigation secrets. ${ }^{36}$ The reasons for such violations are generally divided into two categories: the first being the result of investigators catering to bureaucratic pressure. High-level political figures therefore gain favorable information. Investigators may also have better chances of promotion as a result of providing investigative secrets. ${ }^{37}$

The second category of violation is the leaking of investigation secrets by investigators for media exposure. These types of violations primarily occur due to the poor practice of evaluating the performance of investigators by the amount of media exposure their prosecuting cases receive. This tendency is especially evident in publicly witnessed cases, such as when the accused parties reveal their actions to the public, or voluntarily accept media attention. Due to the intense amount of attention given to publicly witnessed cases by the Taiwanese media, and the broadcasting of the confessions of the defendant (possibly through interviews by anonymous investigators or the media raises questions during the transfer of the defendant), public opinion on the guilt of the defendant is often formed without consideration of the due process of law (public judgment). Such public opinion often only recognizes subjective evidence, while disregarding objective evidence showing inconsistencies between motive and legality. Although the implementation of legal restrictions on the disclosure of evidence through confessions by accused parties through the media have yet been established, if the court holding a specific

\footnotetext{
${ }^{34}$ In practice, during the investigation process in Taiwan, considerations are made to ensure smooth proceedings or prosecution, resulting in the tipping off or leaking of investigation secrets to trial participants. To some extent, such an approach is necessary for finding the truth.

${ }^{35}$ Whether the restriction on the right of the defendant to view investigation case files or exhibits is unconstitutional, is currently being deliberated over by the Justices of the Constitutional Court of the Judicial Yuan.

${ }^{36}$ For example, Judicial Reform Foundation has set up a project on this, available online at $<$ https://www.jrf.org.tw/articles/300>, accessed 21 November 2018.

${ }^{37}$ The Control Yuan has produced a review report, available online at $<w w w . c y . g o v . t w / d l . a s p ?$ fileName $=011261063171$. pdf $>$, accessed 21 November 2018 .
} 
trial finds the defendant not guilty based on evidence unrelated to the public confession of the defendant (see Art. 156 paras. 1, 2 of the CCP), then the court judgment naturally comes into conflict with the opinion of the public.

\subsubsection{Public Discussion of Miscarriages of Justice}

As in the case in Taiwan, high profile criminal cases are a focal point of front pages of newspapers and, ever increasingly, on social media. Even at the early stages of an investigation, sometimes even before prosecutors begin their investigation, criminal cases are the focus of public discussion and speculation. After a case is brought to court, all the way along to the stage of enforcing the judgment, the proceedings are repeatedly discussed in the media. In more conservative newspapers, the focus is mainly on the various cases that heavily influence the political situation or directly influence people's lives. In addition, new electronic newspapers and real-time news, which are not bound by space restrictions, keep a close eye on news of interesting cases and include information of various kinds relevant to the criminal case. Moreover, readers interactively comment, deepening the discussion on these criminal cases. Such information policy is two-edged: While it informs the public, albeit, once a specific atmosphere has been created (possibly helping to convincing the public that the defendant is guilty), it sometimes does not aid in finding the truth, but actually does the opposite.

Newly-emerged social media (such as Facebook, Line, Twitter, etc.) combined with the widespread use of smartphones and other electronic devices have drastically increased media coverage of criminal cases in terms of range, depth and speed. Due to the preference for text-based narration, the content quality of traditional media is substantially higher than that of electronic media. However, there are not many readers who like long in-depth reports. Fast-paced reading habits limit the ability to reflect deeply and decrease the desire to explore the truth. Also, the division between the opposing views of the social community reduces opportunities for exchange. The desire and possibility for dismissing preconceived ideas and exploring the truth is therefore also limited.

As for case decisions in criminal justice practice, there is relatively little discussion in the legal world on whether or not they are influenced, to a certain degree, by the media described above and little discussion on corresponding legal regulations. How to ensure that erroneous information among the many opinions does not influence judicial decisions and follows the principles of oral trial and direct trial, and ensure that the prosecutors and judges pass judgment, in accordance with the principles of law and evidence rather than deliberately following or opposing public opinion, is an important issue which needs to be urgently solved in Taiwan's current criminal justice system. 


\section{Limitations of Fact-Finding in Criminal Proceedings}

As of 2015, Taiwan's CCP has more than thirty amendments. Evidence exclusion laws have also been modified over the years. Originally only one provision, Art. 156 para. 1 of the $\mathrm{CCP},{ }^{38}$ aimed at preventing the coercion of confessions and this protected human rights. Later more provisions were adopted, like Arts. 158-2 and $158-4$ of the CCP in $2003 .^{39}$ There is also specific law that may lead to the exclusion of evidence. For instance, Taiwan's "Communication Security and Surveillance Act” (CSSA: 通訊保障及監察法), ${ }^{40}$ which may even be stricter than the evidence exclusionary laws of the CCP. ${ }^{41}$

Even before exclusionary rules were adopted in 2003, the Supreme Court had already made it clear that "if authorities in a criminal proceeding present wiretap transcripts as evidence, the transcripts shall be excluded if the wiretapping fails to meet the legal requirements and gravely breaches privacy and/or the freedom of correspondence as protected by Art. 12 of the CRC; in order to deter unlawful investigative methods, it would be inappropriate to use such information as evidence." ${ }^{42}$ This decision is one of the rare cases in which a court discusses the admissibility of evidence; according to this decision the exclusion of evidence depends on a balance of the severity of the breach of legal rules when collecting the evidence and the probative value, with a proportionality test eventually deciding on the exclusion of such evidence.

This case law followed the adoption of a balancing approach in 1999, when the Supreme court held that "when deciding whether a piece of evidence that was collected illegally should be excluded, the court must first consider whether the admission of such evidence would jeopardize fairness and justice. A comprehensive assessment that includes consideration of the spirit of the Constitution, the severity of the violation of procedural rules and the damages caused by the crime shall determine whether such evidence must be excluded in order to conform with fairness and justice. ${ }^{, 43}$ In 2003, the newly amended Art. 158-4 of the CCP followed the rationale of this case law, which sets the current legal framework for the exclusion of evidence.

\footnotetext{
${ }^{38}$ About the introduction for Art. 156 para. 1 of the CCP, see below 3.2.

${ }^{39}$ WANG Jaw-Perng, 2011 at 19-20.

${ }^{40}$ Available online at <http://law.moj.gov.tw/LawClass/LawAll.aspx?PCode=K0060044>, officially translated as The Communication Security and Surveillance Act of 14 July 1999 (Status as of 23 May 2018), available online at <http://law.moj.gov.tw/Eng/LawClass/LawContent.aspx? PCODE=K0060044>, accessed 21 November 2018.

${ }^{41}$ Art. $18-1$ para. 3 of the CSSA.

${ }^{42}$ Supreme Court decision 87 taishangzih No. 4025 (最高法院 102 年度台上字第 3254 號判決). In that case, the telephone record was excluded.

${ }^{43}$ Supreme Court decision 88 taishangzih No. 233 (最高法院 88 年度台上字第 233 號判決).
} 


\subsection{General Rules of Evidence Taking (Admissibility of Evidence)}

As has been pointed out above, all information relevant for fact-finding in a criminal case is admitted as evidence in a criminal trial in Taiwan. Nevertheless, the CCP also provides explicitly for the exclusion of evidence. An important feature of Taiwan's framework for the exclusion of evidence is thus its stipulation by a legal rule, rather than by case law.

Its origin lies with the Judicial Yuan (司法院) ${ }^{44}$ : In 2003 the Judicial Yuan proposed a revision of the CCP to the Legislative Yuan (立法院). ${ }^{45}$ The new law stipulates certain circumstances for mandatory exclusion of evidence obtained illegally, e.g. Art. 158-2 of the CCP. Furthermore, the law sets a general rule-Art. 158-4 of the $\mathrm{CCP}$ - for a case-by-case decision in certain situations, including when the evidence was "obtained in violation of the procedure prescribed by the law by an official in execution of criminal procedure", balancing human rights protection and public interest. These exclusionary rules were adopted in September 2003.

According to the current law, when the procedural rules are violated, two forms of evidence exclusion rules exist: Specific (obligatory) exclusionary rules (Arts. 156 para. 1, 158-2 of the CCP) and general (relative) exclusionary rules (Arts. $158-2,158-4$ of the CCP). The following is an introduction of the evidence exclusion rules of the CCP. It will be separated into these two parts.

\subsubsection{Specific Exclusionary Rules of the CCP}

This specific set of rules, Arts. 156 para. 1, 158-2 of the CCP, focuses on oral testimony. It needs special regulation, because the admissibility of oral testimony depends on the voluntariness of the person giving the testimony. The voluntariness of giving such evidence may be often questioned because of certain coercive measures, especially if there is a violation of the investigative procedure. As a result, to promote procedural justice, the $\mathrm{CCP}$ mandates that oral testimony

\footnotetext{
${ }^{44}$ The Judicial Yuan is one of the five branches of government in the Republic of China as stipulated by the Constitution of the Republic of China. The Judicial Yuan is vested with the power of interpretation, adjudication, discipline, and judicial administration; more information available online at <http://www.judicial.gov.tw/aboutus/aboutus00/english.pdf $>$, accessed 21 November 2018.

${ }^{45}$ The Executive Yuan is the executive branch of the government in Taiwan, headed by the premier. The premier is directly appointed by the president, while other members of the Executive Yuan Council, or Cabinet are appointed by the President of the Republic upon the recommendation of the Premier. In addition to supervising the subordinate organs of the Executive Yuan, the Premier explains administrative policies and reports to the Legislative Yuan (Legislature) and responds to the interpellations of legislators; more information available online at $<\mathrm{http}$ ://english. ey.gov.tw/cp.aspx?n=0B5424E21E6FF0A5>, accessed 1 November 2018.
} 
evidence collected by methods that amount to grave breaches of investigative procedure will be considered to lack voluntariness and thus lead to obligatory exclusion. $^{46}$

\subsubsection{Confessions Collected During Specific Periods of Time Mandated by Law or at Night (Art. 158-2 Para. 1 of the CCP)}

The lawmaker appears to especially mistrust confessions obtained during the night or while a defendant is in jail. It is against this backdrop that one must read the different provisions regulating the exclusion of confessions, especially specific constitutional law and the key provision of the CCP: Art. 158-2.

According to Art. 8 para. 2 of the Constitution of the Republic of China (CRC) ${ }^{47}$ when a person is arrested or detained on suspicion of having committed a crime, the organ making the arrest or detention shall, within $24 \mathrm{~h}$, turn him over to a competent court for trial. The $24 \mathrm{~h}$ limitation refers to the actual time that can be used for investigation. Art. 93-1 of the $\mathrm{CCP}^{48}$ provides reasons of delay that shall not be counted in the $24 \mathrm{~h}$ time limitation. These reasons include: the time used for transferring the defendant, the time used to wait for bonds to be presented or for the acceptance of custody, the time when being examined by the court, unavoidable delay caused by traffic or force majeure, examination not being possible due to health related emergency suffered by the defendant, the examination not going ahead due to no defense attorney, an assisting person authorized by law or an interpreter being present. To respect human rights and to ensure the legality of these procedures, there shall be no examination or interrogation conducted should these circumstances prevail and at night. Otherwise the testimony collected is, in principle, inadmissible.

The key provision is Art. 158-2 para. 1 of the CCP. This provision, however, allows for exceptions which are combined with the good-faith-doctrine ${ }^{49}$ and voluntary doctrine, according to Art. 158-2 para. 1: "provided that a lack of bad faith in such violations and the voluntariness of the confession or statement has been proven, the preceding section shall not apply."

Applying Art. 158-2 para. 1 of the CCP, the Supreme Court held that unless a defendant consents (according to Art. 100-3 para. 1 of the $\mathrm{CCP}^{50}$ ), no interrogation may take place at night. The burden to prove an exception is on the

\footnotetext{
${ }^{46}$ See LIN Yu-Hsiung, 2013 (I) at 190-91.

${ }^{47}$ See Annex.

${ }^{48}$ See Annex.

${ }^{49}$ See references to the (US-American) good-faith-doctrine exception United States v. Leon, 468 US 897 (1984). See ZHU Shi-Yan, 2015 at 161.

${ }^{50}$ It states that the interrogation of a defendant by police shall, in principle, not proceed at night; exceptions are (1) express consent by the person being interrogated, (2) identity check of the person arrested with or without a warrant at night, (3) permission by a public prosecutor or judge, or (4) in case of emergency, see Annex.
} 
prosecutor. ${ }^{51}$ However, only if night-time interrogation amounts to coercion prohibited by Art. 156 para. 1 of the $\mathrm{CCP}^{52}$ is the oral testimony inadmissible, regardless of whether consent has been acquired. ${ }^{53}$

\subsubsection{Right to Remain Silent and Access to a Defense Attorney (Art. 158-2 Para. 2 of the CCP)}

Taiwanese law grants the defendant the right to remain silent and the right to have a defense lawyer.

Authorities must inform the defendant of his or her rights: Art. 95 para. 1 cll. 2 and 3 of the CCP provides for the duty to inform the defendant, among other things, about the right to remain silent and the right to access a defense attorney. This rule is important because the defendant may not be familiar with his legal rights or how to exercise his rights. In order to ensure that police officers and other investigative officials follow the rule, Art. 158-2 para. 2 of the CCP provides that the oral testimony acquired without complying with the duty to inform is inadmissible. ${ }^{54}$ However, the good-faith-doctrine and voluntary doctrine ${ }^{55}$ applies here also. ${ }^{56}$

The fact that the Taiwanese judiciary will not tolerate violations of the duty to caution a defendant also becomes clear when looking at the interpretation of Art. 158-2 para. 2 of the CCP: The Supreme Court held that after an arrest, the suspect must be read his rights by police, irrespective of whether a subsequent questioning takes place in form of a (formal) interrogation or an informal chat. Only such an interpretation of Art. 158-2 para. 2 of the CCP is in conformity with the spirit of Art. 9 cl. 2 of the International Covenant on Civil and Political Rights. ${ }^{57}$

\subsubsection{Specific Exclusionary Rules of the Communication Security and Surveillance Act}

Specific rules also apply when investigations take place in secret:

Art. 18-1 of the Communication Security and Surveillance Act (CSSA: 通訊保 障及監察法) provides that any content acquired through communications surveillance enforced in accordance with Arts. 5, 6 or 7, or any evidence derived

\footnotetext{
${ }^{51}$ Supreme Court decision 100 taishangzih No. 4577 (最高法院 100 年度台上字第 4577 號判 決).

${ }^{52}$ The introduction for Art. 156 para. 1 of the CCP, see below 3.2.

${ }^{53}$ Supreme Court decision 98 taishangzih No. 6024 (最高法院 98 年度台上字第 6024 號制決).

${ }^{54}$ E.g. Supreme Court decision 104 taishangzih No. 3936 (最高法院 104 年度台上字第 3936 號 判決).

${ }^{55}$ Above 3.1.1.1.

${ }^{56}$ Supreme Court decision 100 taishangzih No. 4163 (最高法院 100 年度台上字第 4163 號制 決).

${ }^{57}$ Supreme Court decision 99 taishangzih No. 1893 (最高法院 99 年度台上字第 1893 號制決).
} 
from such surveillance that is not related to the purpose of the surveillance, shall not be used as evidence or for any other purpose in any judicial investigation, judgment or other proceeding.

Before January 2014, Arts. 5 and 6 of the CSSA adopted a relative exclusionary model,${ }^{58}$ the law provided that if the surveillance amounts to a grave breach of the rules, the acquired content and the derived evidence shall not be admitted as evidence. According to these rules, the Supreme Court ruled that if a state official responsible for a criminal investigation fails to acquire an interceptive warrant, then the conduct is not only an arbitrary misconduct that violates the "warrant requirement" of the law, but is also a severe infringement of people's freedom of private communications and privacy. The admissibility of the content acquired shall be decided according to the Communication Security and Surveillance Act. ${ }^{59}$ However, following the amendment of Art. 18-1 in the CSSA in January 2014, the law now mandates that the acquired content shall not be admissible if the surveillance was conducted illegally or if the content is not related to the purpose of the surveillance. The new law adopts an obligatory exclusionary model. ${ }^{60}$

This specific exclusionary rule thus does not only prevent the use of information that was acquired illegally, but also excludes information subsequently obtained, based on tainted evidence. It is noteworthy that this provision is the only law that recognizes a fruit of poisonous tree doctrine in Taiwan's criminal justice system. The CCP does not acknowledge such a rule for other violations of procedural rules, nor did courts elsewhere recognize such a doctrine in the past. The Supreme Court once ruled that "when officials in execution of criminal procedure collect evidence illegally and use that piece of evidence to acquire derived evidence, irrespective of the causal relationship of the original evidence and the derived evidence, as long as the derived evidence is acquired lawfully and the investigation process is independent from the previous action, it shall not be excluded by the CCP. However, if the procedure of the previous unlawful evidence collection is not independent from the subsequent evidence collection and the previous evidence contaminated the investigation and collection of the derived evidence, only then may the court apply the evidence exclusionary rules from the CCP to exclude the derived evidence." ${ }^{\prime 1}$

\subsubsection{General Exclusionary Rules of the CCP}

Besides specific exclusionary rules explained in the previous paragraphs, Taiwanese law provides a general rule, Art. 158-4 of the CCP. This article provides

\footnotetext{
${ }^{58}$ According to the current law, when the procedural rules are violated, two forms of evidence exclusionary rules exist: obligatory exclusionary rules and relative exclusionary rules. See above 3.1.

${ }^{59}$ Supreme Court decision 98 taishangzih No. 1495 (最高法院 98 年度台上字第 1495 號制決). ${ }^{60}$ ZHU Shi-Yan, 2015 at 158.

${ }^{61}$ Supreme Court decision 102 taishangzih No. 3254 (最高法院 102 年度台上字第 3254 號判 決).
} 
that "the admissibility of the evidence obtained in violation of the procedure prescribed by the law by an official in execution of criminal procedure shall be determined by balancing the protection of human rights and the preservation of public interests, unless otherwise provided by law."

This article provides that, except for the obligatory exclusion rules, the admissibility of other unlawfully collected evidence shall be determined on a case-by-case basis, by balancing human rights protection and public the interest. The court shall consider things such as due process of law, right to a fair trial, the integrity of the judicial system and proportionality. The goal is to reach a balancing point between human rights and protection of the public interest, two seemingly contradictory ideas. The legislative note provided a list of factors that should be taken into account of the balancing test ${ }^{62}$ : (a) The circumstances of the violation of the procedure prescribed by the law take into account whether there were difficulties in collecting evidence lawfully; (b) The subjective intentions of the official, i.e. whether the official knows his conduct is unlawful; (c) The nature and the severity of the right that was infringed, i.e. the circumstances of the infringement; (d) The risk and harm of the crime, i.e. the nature of the crime and its circumstances; (e) The deterrence effect of excluding such evidence; (f) Whether it is unavoidable that officials will discover such evidence using the procedure prescribed by law (the standard may be relaxed if such evidence can be acquired through normal proceedings); (g) The effect the unlawful evidence has on the defense of the defendant. In sum, the law authorizes the court to have discretion according to the specific circumstances of the case. $^{63}$

After the enactment of Art. 158-4 of the CCP, the Supreme Court re-emphasized the legislative note through a precedent. The Court ruled in Supreme Court precedent $93^{64}$ that "referring to evidence collected by unlawful search, in order to take into account of both procedural justice and the obligation to seek the truth, courts shall decide objectively on the protection of human rights and the preservation of social security on a case-by-case basis, and in accordance with proportionality and the interest balancing principle." The Court also provided guidance regarding the factors to be considered. These factors are generally the same as the factors in the legislative note, except "the circumstances of the violation of the procedure prescribed by the law" was replaced by the "severity of the violation of the procedure prescribed by the law" and "the conditions of the violation of the procedure prescribed by the law when it happened."

\footnotetext{
62،人權保障及公共利盆之均衡維護, 如何求其平衡, 因各國國情不同, 學說亦是理論紛歧, 依 實務所見, 一般而言, 違背法定程序取得證據之情形, 常因個案之型態、情篩、方法而有差 異, 法官於個案權衡時, 允宜煁酌 (1) 違背法定程序之情節。(2) 違背法定程序時之主觀意 圖。(3) 侵害犯罪嫌疑人或被告權㿽之種類及輕重。(4) 犯罪所生之危險或實害。(5) 禁止使 用證據對於預防將來違法取得證據之效果。(6) 偵審人員如依法定程序有無發現該證據之 必然性及 (7) 證據取得之違法對被告訴訟上防禦不利盆之程度等各種情形, 以爲認定證據能 力有無之標準, 俾能兼顧理論與實際, 而應需要。”.

${ }^{63}$ LIN Yu-Hsiung, 2013 (I) at 616-17; ZHU Shi-Yan, 2015 at 166-67.

${ }^{64}$ Supreme Court decision 93 taishangzih No. 664 (最高法院 93 年台上字第 664 號判例).
} 


\subsection{Exclusion of Evidence Obtained by Torture and Undue Coercion}

The information obtained by applying torture or coercing the defendant is to be mandatorily excluded and is, accordingly, inadmissible as evidence in criminal trials in Taiwan (see Art. 156 para. 1 of the CCP).

\subsubsection{Definitions of Torture, Undue Coercion and Degrading Punishment}

The Taiwanese criminal justice system clearly rejects torture (see. Art. 98 of the CCP, Art. 125 of the CCRC). However, one cannot find a clear-cut definition of torture or undue coercion in the CCP or in the Criminal Code of the Republic of China. Art. 8 of the Constitution of the Republic of China does enshrine personal liberty as being one of the most fundamental rights against undue physical harm or improper detention. However, the wording of the Constitution article is extremely concise.

At the level of legislation, Art. 125 para. $1 \mathrm{cl} .2$ of the CCRC threatens investigators with criminal punishment in the case of torture. ${ }^{65}$ The corresponding statute provision on this issue in the CCP is Art. $98 .^{66}$

\subsubsection{Definitions of Right to Remain Silent/Privilege Against Self-incrimination}

The CCP expressly accords the defendant the right to silence and the privilege against self-incrimination in Art. 95 para. 1 cl. $2 .^{67}$

On 22 April 2009, the Legislature in Taiwan adopted the "Act to Implement the International Covenant on Civil and Political Rights and the International Covenant on Economic, Social and Cultural Rights". ${ }^{68}$ The law came into effect on 10 December (Human Rights Day) the same year. Art. 2 of this Act stipulates: "Human rights protection provisions in the two Covenants have domestic legal status". ${ }^{69}$ The ICCPR became part of national law in Taiwan from as of that day. ${ }^{70}$

\footnotetext{
${ }^{65}$ See Annex.

${ }^{66}$ See Annex.

${ }^{67}$ See Annex.

68 公民與政治權利國際公約及經濟社會文化權利國際公約施行法. The text is available online at <http://law.moj.gov.tw/Law/LawSearchResult.aspx?p=A\&k1=\%E5\%85\%AC\%E7\%B4\%84\% $\mathrm{E} 6 \% 96 \% \mathrm{BD} \% \mathrm{E} 8 \% \mathrm{~A} 1 \% 8 \mathrm{C} \% \mathrm{E} 6 \% \mathrm{~B} 3 \% 95 \& \mathrm{t}=\mathrm{E} 1 \mathrm{~F} 1 \mathrm{~A} 1 \& \mathrm{TPage}=1>$, official English translation at <http://law.moj.gov.tw/Eng/LawClass/LawContent.aspx?PCODE=I0020028>, accessed 21 November 2018.

69“兩公約所揭示保障人權之規定, 具有國內法律之效力”.

${ }^{70}$ For more information, see below 3.2.7.
} 


\subsubsection{Exclusionary Rules for Evidence (Possibly) Obtained by Torture and Undue Coercion}

As in most criminal justice systems, Taiwan has special rules for evidence obtained by torture or undue coercion.

\subsubsection{Legal Framework}

Art. 156 para. 1 of the CCP was introduced for the purpose of assuring the applicability of the aforementioned Art. 98 of the CCP. ${ }^{71}$ The word "violence" refers to Art. 98 of the CCP and can be interpreted as "torture" in a general sense ${ }^{72}$; the other five items provided as examples of improper means of extracting incriminating statements are seen as undue coercion. ${ }^{73}$

\subsubsection{Practice; (High Court) Jurisprudence}

The law excluding involuntary statements made by the defendant has basically been set by the Taiwanese judiciary-including district courts, high courts and the Supreme Court. The legal reasoning of Taiwanese courts is generally extremely short and simple, maybe due to the tradition of conciseness in Chinese literature. But in some cases the Supreme Court explained specific issues more detailed. Following are three explanations given for a possible exclusion of evidence. This reasoning also highlights the rationale behind exclusionary rules-from the point of view of the courts.

\section{Protecting Human Dignity of the Defendant and His Status as a Party}

The judgment refers to the safeguarding of the human dignity of the defendant and his status as a party to the trial proceedings as the rationale for the exclusion of confessions retrieved from an interrogation that lasted too long and become oppressive to the interrogated person. Accordingly, such a confession is absolutely inadmissible without exception and subject to no discretion by the trial court. ${ }^{74}$

\footnotetext{
${ }^{71}$ See Annex.

${ }^{72}$ ZHU Shi-Yan, 2015 at 175.

${ }^{73}$ LIN Yu-Hsiung, 2013 (I) at 191.

${ }^{74}$ Supreme Court decision 104 taishangzih No. 3052 (最高法院 104 年度台上字第 3052 號判 決).
} 


\section{Safeguarding the Liberty of Decision Making and Mental Activities of the Defendant}

In an extraordinary appeal ${ }^{75}$ case, the Supreme Court held: "The combination of Art. 98 and Art. 156 para. 1 of the CCP constitutes a complete exclusionary rule on involuntary confession. With this ruling the court aims to secure the voluntariness of statements, liberty of decision making and mental activities of the defendant."76

\section{Deterrence from Illegal Investigatory Activity Based on the Principle of the Due Process of Law}

The Supreme Court expressed in another case involving illegal search activities that exclusionary rules are based on constitutional requirements and are intended to have a deterrent effect: By excluding evidence illegally obtained by law-enforcement agencies due process will be upheld and the police will be deterred from illegal activities in collecting evidence. ${ }^{77}$ This explanation can be seen as a general statement, an effort to underpin the application of all exclusionary rules (not only those related to illegal searches).

\subsubsection{Institutional Arrangements Securing the Ban on Torture Undue Coercion}

The Supreme Court confirmed the Art. 156 para. 3 of the $\mathrm{CCP}^{78}$ requirement that demands a prioritized investigation while citing an earlier case: "As long as the defendant claims his previous confession was made involuntarily, the court should investigate this claim before other matters. The court should instruct the prosecutor to introduce the means by which the defendant gave his confession and that this was voluntary. The means for establishing the voluntariness may include an audio-record of video-record of, or witness to the whole proceeding of the interrogation in question."79 In addition, "if the defendant's confession of the offense was extracted by violence, threat, inducement, fraud, exhausting interrogation, unlawful detention or other improper means, the law-enforcement officers are likely to bear administrative or

\footnotetext{
${ }^{75}$ The extraordinary appeal, according to Chapter VI of the CCP, is a special relief litigation procedure filed with the Supreme Court by the Prosecutor General of the Supreme Prosecutors Office for a conclusive criminal judgment on the grounds that the judgment in question was made contrary to the law. Thus the object of an extraordinary appeal is to obtain a conclusive criminal judgment or an arbitral award which has substantially the same effect as a sentence of inflicting punishment, provided that the judgment or litigation procedure is against the law. More information available online at the homepage of the Supreme Prosecutors Office $<\mathrm{http}: / / w w w . t p s . m o j$. gov.tw/ct.asp?xItem=31768\&CtNode=12112\&mp=096>, accessed 21 November 2018 .

${ }^{76}$ Supreme Court decision 104 taifeizih No. 212 (最高法院 104 年度台非字第 212 號判決).

${ }^{77}$ Supreme Court decision 99 taishangzih No. 3168 (最高法院 99 年度台上字第 3168 號判決).

${ }^{78}$ See above 2.1.1.3.

${ }^{79}$ Supreme Court decision 91 taishangzih No. 2908 (最高法院 91 年度台上字第 2908 號制決).
} 
criminal liability. Under such circumstances, one cannot reasonably expect the officers in charge to tell the truth while taking the stand as a witness. Thus when the defendant raised a claim alleging that his confession was extracted involuntarily, the court should have undertaken an in-depth investigation into such claims. It is not supposed to dismiss the defendant's claim only on the ground that the officers responsible for the interrogation testified that the confession had been given voluntarily." 80

\subsubsection{Exclusion of Evidence or Other Remedies Following a Breach of the Ban on Torture and Undue Coercion}

Apart from the exclusion of the improperly obtained evidence, ${ }^{81}$ the victims of torture or similar improper means of investigation which violate Art. 98 of the $\mathrm{CCP}^{82}$ are entitled to financial compensation for the injury or damage they suffered or the loss of freedom caused accordingly, following the State Compensation Law (國家賠償法 ${ }^{83}$ ) or the Law of Compensation for Wrongful Detentions and Executions (刑事補償法 ${ }^{84}$ ). The policemen, investigators, or prosecutors who are liable for such wrongdoing may be prosecuted. They may be sued-also by the State - and asked to reimburse the payment already made by the Government to the victim. In addition, the liable law-enforcement officers and/or prosecutors may also face administrative disciplinary measures.

\subsubsection{Admissibility of Indirect Evidence ("Fruits of Poisonous Tree") in Cases of Torture and Undue Coercion}

\subsubsection{Legal Framework}

As pointed out at the beginning of this paper, both the Taiwanese courts and public attach great importance to coherent fact-finding: The search for the truth is important. Therefore, one finds only few exclusionary rules and one cannot or will not find a statutory rule acknowledging the fruit of poisonous tree doctrine and generally banning the admission of evidence deriving from tainted evidence, for instance, an involuntary confession or an illegal search without warrant. However,

\footnotetext{
${ }^{80}$ Supreme Court decision 100 taishangzih No. 4430 (最高法院 100 年度台上字第 4430 號制 決).

${ }^{81}$ See above 3.2.1.

${ }^{82}$ With reference to Art. 98 of the CCP, see above 3.2.1 and 3.2.3.1.

${ }^{83}$ Officially translated as State Compensation Law of 2 July 1980 (Status as of 2 July 1980), available online at <http://law.moj.gov.tw/Eng/LawClass/LawContent.aspx?PCODE=I0020004>, accessed 21 November 2018.

${ }^{84}$ Officially translated as Law of Compensation for Wrongful Detentions and Executions of 11 June 1959 (Status as of 11 July 2007), available online at <http://law.moj.gov.tw/Eng/LawClass/ LawContent.aspx?PCODE=C0010009>, accessed 21 November 2018.
} 
Art. 18-1 of the Communication Security and Surveillance Act provide for exclusion of evidence if a secret surveillance investigation gravely violated procedural rules. Then neither the information gained nor any "derived evidence" shall be admitted in court. The parliament adopted this statute after it had been victim to a bugging scandal. ${ }^{85}$

\subsubsection{Practice; (High Court) Jurisprudence}

Based on a principle of judicial interest balance that underlines Art. 158-4 of the CCP, the Supreme Court adopted a discretionary exclusionary standard for dealing with the evidence generally known as the fruit of poisonous tree doctrine. Thus is held that "unlike the American practice that excludes tainted evidence derived from previous illegally obtained evidence, a different approach is taken in this country. Namely, while the secondary evidence derived from the previous improperly obtained evidence should be excluded, the evidence acquired by an independent legitimate investigation shall not be suppressed." 86 It appears that, as the Court tried hard to draw a distinction from the American fruit of poisonous tree doctrine, the previous ruling in fact makes differs little from the local ruling because the American fruit of poisonous tree doctrine also bears certain exceptions and renders itself far from a mandatory rule of exclusion.

\subsubsection{Effect of International Human Rights}

International human rights do have an impact on the Taiwanese criminal justice system, especially when exclusionary rules are applied:

For instance, when weighing the "defendant's rights" and the "public interest in criminal prosecution" (Art. 158-4 of the CCP), the protection of human rights by international human rights covenants should also be taken into consideration, especially the "International Covenant on Civil and Political Rights" (ICCPR). ${ }^{87}$ For geopolitical reasons, Taiwan is no longer a member of the United Nations (UN), it has, however, adopted the ICCPR, although it could not deposit the documents accordingly with the UN. In order to demonstrate its conformity with international human rights, Taiwan passed the "Act to Implement the International Covenant on Civil and Political Rights and the International Covenant on Economic, Social and Cultural Rights" in 2009. Art. 2 of this instrument states that "[h]uman rights protection provisions in the two Covenants have domestic legal status". The ICCPR has become the human rights law that Taiwan's prosecution personnel must respect,

\footnotetext{
${ }^{85}$ YANG Yun-Hua, 2014-7 at 3-4.

${ }^{86}$ Supreme Court decision 102 taishangzih No. 4177 (最高法院 102 年度台上字第 4177 號判 決).

${ }^{87}$ LIN Yu-Hsiung, 2013 (I) at 25-26; ZHU Shi-Yan, 2015 at 645.
} 
especially the fair trial-clause in Art. 14 of the ICCPR. Thus in when deciding on possible exclusion of evidence, the authorities (i.e. all levels of governmental institutions and agencies) ${ }^{88}$ have to consider these international human rights. Taiwan is no longer confined to its original provisions on human rights. ${ }^{89}$

Despite Taiwan's solitude in a geopolitical and diplomatic context, the national laws and legislation have been heavily influenced by the most well-known international instruments on human rights, such as United States Declaration of Independence, the Declaration of Human Rights of the French Revolution, the ICCPR adopted by the United Nations General Assembly, and the European Convention for the Protection of Human Rights and Fundamental Freedoms. They can often be found in the prologues, grounds and justifications of relative laws, and the Judicial Yuan Interpretations (JYI: 司法院大法官解釋). ${ }^{90}$

\section{Statistics}

Empirical research on crime and statistical criminal information have both always been neglected areas in Taiwanese criminal law. These are not only relevant topics for academic research or studies of interest; even the judicial statistics of the authorities $^{91}$ and statistical reports created by the Judicial Yuan ${ }^{92}$ put special emphasis on items such as the number of criminal cases received and finalized. Therefore, exclusion of evidence or evidence material are both lacking as specific research topics or statistical items.

The contents of Taiwanese criminal judgments (not including prosecution investigation documents, such as indictments or non-prosecutorial dispositions), apart from specific documents prohibited from disclosure, can in principle be found on the Judicial Yuan's Law and Regulations Retrieving System ${ }^{93}$ or private judicial databases such as Lex Data. ${ }^{94}$ Using the words "exclusion of evidence" (including "not to be used as evidence", but also eliminated especially because of the hearsay principle) as a query, there are many results. If we just take the Supreme Court as an example, there are already more than three thousand query results. In District

\footnotetext{
${ }^{88}$ See Art. 4 of the Act to Implement the International Covenant on Civil and Political Rights and the International Covenant on Economic, Social and Cultural Rights.

${ }^{89}$ LIN Yu-Hsiung, 2013 (I) at 26.

${ }^{90}$ E.g. Interpretation Nos. 392 (The "court" provided in Article 8 of the Constitution does not include the "prosecutor's office", hence not empower the prosecutor to detain a person beyond the 24-h period as authorized by said Article for the court.), 582 (the relevant precedents holding that a statement made by a criminal co-defendant against another co-defendant may be admissible are unconstitutional.).

${ }^{91}<$ https://www.moj.gov.tw/mp-001.html>, accessed 21 November 2018.

${ }^{92}<\mathrm{http}: / /$ www.judicial.gov.tw>, accessed 21 November 2018.

${ }^{93}<$ http://jirs.judicial.gov.tw/Index.htm>, accessed 21 November 2018.

${ }^{94}<$ http://fyjud.lawbank.com.tw/index.aspx>, accessed 21 November 2018.
} 
Courts, there are a number of times more. Therefore, more detailed and accurate proof and statistical information of evidence exclusion can only be found if exclusion of evidence becomes a subject for empirical research or research projects. Only when criminal judgments are extensively collected, analyzed, concluded and dealt with can there be a way.

After the adoption of evidence rules, the Supreme Court frequently discussed issues arising from the difficult question of when evidence should actually be excluded in a specific case. This is an indicator of the importance attached to these rules. According to standing case law the admissibility of evidence shall be decided on the basis of factors including due process of law, the integrity of the judicial system and the deterrence effect for unlawful collection of evidence. Ultimately the exclusion of illegally obtained evidence is decided case-by-case, based on a balancing test, albeit a "relative exclusionary model". Only if the law explicitly mandates the exclusion of evidence, there is no space for balancing. A search of the Judicial Yuan's decision database gives the following result: From February 2003, when Art. 158-4 of the CCP was enacted until December 2015, the Supreme Court assessed 258 cases on possible exclusion of evidence using the balancing test. Among these cases, 155 cases were remanded because the lower court had failed to apply the balancing test in its decision. A total of 103 cases were upheld and in 95 cases the Court held that the evidence at stake was admissible and in only in 8 cases it opted for inadmissibility.

\section{Conclusion}

The Taiwanese criminal justice system is still struggling to find the appropriate balance between truth finding and protection of individual rights when investigating crime and prosecuting a case. On the one hand, in order to find substantive truth, all relevant evidence appears to be needed, even if it is obtained as a result of the investigating authorities infringing human rights. On the other hand, not only the people, but also the government is bound by law and thus the rule of law is a principle to be followed by all official authorities. Each country handles this issue differently. The Taiwanese CCP provides defendants with various entitlements, including the right to counsel, the right to information, the right to an audio/video recording of any interrogation, the right to remain silent and exclusionary rules ensuring that the relevant individual rights in the criminal process are protected. Whether or, rather, how these rights are granted in practice is yet another question, as is the question of what remedies an individual has in cases of violation of these rights.

The CCP's exclusionary rules, adopted in 2003, were meant to safeguard the rule of law and judicial integrity. The lawmaker acted in the firm belief that an exclusion of evidence obtained through torture, undue coercion or other misconduct of the authorities will send a message - to the public and investigating authorities alikethat courts will condemn any lawless acts. 
Today, the Taiwanese CCP adopts a multitrack approach to the exclusion of evidence. In some cases, for example, the information obtained by applying torture or undue coercion to a defendant is to be mandatorily excluded and thus inadmissible as evidence in criminal trials (Art. 156 para. 1 of the CCP). In some other cases, the court is to balance the interest in finding truth and individual rights. The catch-all clause is prescribed in Art. 158-4 of the CCP to allow the court to exclude evidence illegally obtained after considerations.

More than a decade after adopting exclusionary rules as part of the procedural law it appears that the rules are still a work in progress and pose, in fact, a challenge to the various stakeholders in the criminal justice system. It seems to be too early to decide whether exclusionary rules have proven to be effective tools in safeguarding human rights, while at the same time securing the search for the truth in a criminal case.

\section{Code of Criminal Procedure (CCP: 刑事訴訟法)}

\begin{tabular}{|c|c|}
\hline Chinese & English \\
\hline $\begin{array}{l}\text { 第 } 2 \text { 條第 } 1 \text { 項 } \\
\text { 實施刑事訴訟程序之公務員, 就該管案件, } \\
\text { 應於被告有利及不利之情形, 一律注意。 }\end{array}$ & $\begin{array}{l}\text { Art. } 2 \text { para. } 1 \\
\text { A public official who conducts proceedings in } \\
\text { a criminal case shall give equal attention to } \\
\text { circumstances both favorable and unfavorable } \\
\text { to an accused }\end{array}$ \\
\hline $\begin{array}{l}\text { 第 } 27 \text { 條 } \\
\text { I. 被告得隨時選任辯護人。犯罪嫌疑人受 } \\
\text { 司法警察官或司法警察調查者, 亦同。 } \\
\text { II. 被告或犯罪嫌疑人之法定代理人、配 } \\
\text { 偶、直系或三親等內旁系血親或家長、家 } \\
\text { 屬, 得獨立爲被告或犯罪嫌疑人選任讋護 } \\
\text { 人。 } \\
\text { III. 被告或犯罪嫌疑人因精神障礙或其他 } \\
\text { 心智缺陷無法爲完全之陳述者, 應通知前 } \\
\text { 項之人得爲被告或犯罪嫌疑人選任辯護 } \\
\text { 人。但不能通知者, 不在此限。 }\end{array}$ & $\begin{array}{l}\text { Art. } 27 \\
\text { I. An accused may at any time retain defense } \\
\text { attorneys. The same rule shall apply to a } \\
\text { suspect being interrogated by judicial police } \\
\text { officers or judicial policemen } \\
\text { II. A statutory agent, spouse, lineal blood } \\
\text { relative, collateral blood relative within the } \\
\text { third degree of kinship, family head, or } \\
\text { family member may independently retain } \\
\text { defense attorneys for the accused or suspect } \\
\text { III. In case an accused or a suspect is unable } \\
\text { to make a complete statement due to unsound } \\
\text { mind, the persons listed in the preceding } \\
\text { section shall be notified of the same, provided } \\
\text { that the said notification is not required if it } \\
\text { can not be made practically }\end{array}$ \\
\hline $\begin{array}{l}\text { 第 } 34 \text { 條第 } 1 \text { 項 } \\
\text { 辯護人得接羈押之被告, 並互通書信。 } \\
\text { 非有事證足認其有湮隇、絾造、變造證據 } \\
\text { 或勾串共犯或證人者, 不得限制之。 }\end{array}$ & $\begin{array}{l}\text { Art. } 34 \text { para. } 1 \\
\text { A defense attorney may interview and } \\
\text { correspond with a suspect or an accused } \\
\text { under detention, provided that if facts exist } \\
\text { sufficient to justify an apprehension that such } \\
\text { defense attorney may destroy, fabricate, or } \\
\text { alter evidence or form a conspiracy with a } \\
\text { co-offender or witness, such interviews or } \\
\text { correspondence may be limited }\end{array}$ \\
\hline
\end{tabular}


(continued)

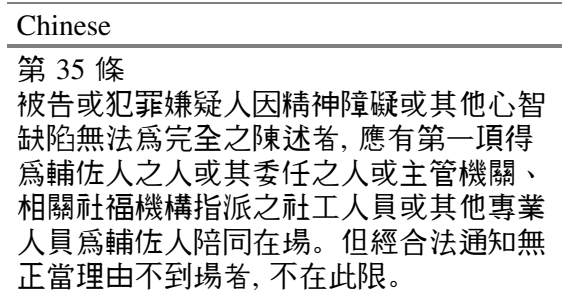

第 91 條

I. 第 91 條及前條第 2 項所定之 24 小時, 有

下列情形之一者, 其經過之時間不予計

入。但不得有不必要之遲延:

一、因交通障疑或其他不可抗力事由所生

不得已之遲滞。

二、在途解送時間。

三、依第 100 條之 3 第 1 項規定不得爲詢

問者。

四、因被告或犯罪嫌疑人身體健康突發之

事由, 事實上不能訊問者。

五、被告或犯罪嫌疑人因表示選任辯護人

之意思, 而等候辯護人到場致未予訊問

者。但等候時間不得逾 4 小時。其等候第

31 條第5 項律師到場致未予訊問或因精神

障礙或其他心智缺陷無法爲完全之陳述,

因等候第 35 條第 3 項經通知陪同在場之

人到場致未予訊問者, 亦同。

六、被告或犯罪嫌疑人須由通譯傳譯, 因

等候其通譯到場致未予訊問者。但等候時

間不得逾 6 小時。

七、經檢察官命具保或責付之被告, 在候

保或候責付中者。但候保或候責付時間不

得逾四小時。

八、犯罪嫌疑人經法院提審之期間。

II. 前項各款情形之經過時間內不得訊問。

III. 因第1項之法定障礙事由致 24 小時內

無法移送該管法院者, 檢察官聲請羈押時, 並應釋明其事由。
English

Art. 35

In cases an accused or a suspect is unable to make a complete statement due to unsound mind, he shall be accompanied by one of the qualified assistant, under the first section of this article, or his authorized agent, or a social worker appointed by a governmental agency in charge thereof; provided that if, upon being properly served, the persons who shall accompany the accused or suspect fail to appear without good reason, the provision of this section shall not apply

Art. 91

I. Time spent in one of the following circumstances shall not be counted against the twenty-four hour limitation in Article 91 and the second section of the preceding article, provided that there is no unnecessary delay:

(1) unavoidable delay caused by traffic obstruction or force majeure;

(2) in the transfer of arrestee;

(3) interrogation cannot be made according to the first section of Article 100-3;

(4) examination cannot be made due to health emergency of the accused or suspect;

(5) examination is not made because of waiting for the presence of a defense attorney when the accused or suspect has made the presentation that a defense attorney has been retained. The said waiting time allowed shall not exceed four hours. The same rule applies to the case while waiting for the presence of the persons named in the third section of Article 35 if the accused or the suspect is unable to make a clear and complete statement due to unsound mind;

(6) examination is not made because of waiting for the presence of the interpreter if there is a need for having an interpreter for the accused or suspect, provided that the waiting time shall not exceed six hours; (7) if the public prosecutor orders the release of the arrestee on bail or to the custody of another, while waiting for bonds to be presented or for the acceptance of custody, provided that the waiting time allowed shall not exceed four hours; or 
(continued)

\begin{tabular}{|c|c|}
\hline Chinese & English \\
\hline & $\begin{array}{l}\text { (8) the time when the suspect was examined } \\
\text { by the court according to the Habeas Corpus } \\
\text { Act } \\
\text { II. No examination shall be made in the above } \\
\text { period of time described in the preceding } \\
\text { section } \\
\text { III. If the accused cannot be sent to a court } \\
\text { with jurisdiction within twenty-four hours } \\
\text { due to the existence of one of the reasons } \\
\text { specified in the first section of this article, the } \\
\text { public prosecutor shall specify the reason in } \\
\text { his application of detention order }\end{array}$ \\
\hline $\begin{array}{l}\text { 第 } 95 \text { 條第 } 1 \text { 項 } \\
\text { I. 訊問被告應先告知下列事項: } \\
\text { 一、犯罪嫌疑及所犯所有罪名。罪名經告 } \\
\text { 知後, 認爲應變更者, 應再告知。 } \\
\text { 二、得保持縅默, 無須違背自己之意思而 } \\
\text { 爲陳述。 } \\
\text { 三、得選任辯護人。如爲低收入戶、中低 } \\
\text { 收入戶愿住民或其他依法令得請求法律 } \\
\text { 扶助者, 得請求之。 } \\
\text { 四、得淸求調查有利之證據。 }\end{array}$ & $\begin{array}{l}\text { Art. } 95 \text { para. } 1 \\
\text { I. In an examination, an accused shall be } \\
\text { informed of the following: } \\
\text { (1) that he is suspected of committing an } \\
\text { offense and all of the offenses charged. If the } \\
\text { charge is changed after an accused has been } \\
\text { informed of the offense charged, he shall be } \\
\text { informed of such change; } \\
\text { (2) that he may remain silent and does not } \\
\text { have to make a statement against his own } \\
\text { will; } \\
\text { (3) that he may retain defense attorney; and } \\
\text { (4) that he may request the investigation of } \\
\text { evidence favorable to him }\end{array}$ \\
\hline $\begin{array}{l}\text { 第 } 98 \text { 條 } \\
\text { 訊問被告應出以想切之態度, 不得用強 } \\
\text { 暴、脅迫、利誘、詐欺、疲勞訊問或其他 } \\
\text { 不正之方法。 }\end{array}$ & $\begin{array}{l}\text { Art. } 98 \\
\text { Violence, threat, inducement, fraud, } \\
\text { exhausting examination or other improper } \\
\text { means may not be applied during the } \\
\text { interrogation of the defendant }\end{array}$ \\
\hline $\begin{array}{l}\text { 第 } 100 \text { 條之 } 1 \text { 第 } 1 \text { 項 } \\
\text { 訊問被告, 應全程連續錄音; 必要時, 並應 } \\
\text { 全程連續錄影。但有急迫情況且經記明筆 } \\
\text { 錄者, 不在此限。 }\end{array}$ & $\begin{array}{l}\text { Art. } 100-1 \text { para. } 1 \\
\text { The whole proceeding of examining the } \\
\text { accused shall be recorded without } \\
\text { interruption in audio, and also, if necessary, } \\
\text { in video, provided that in case of an } \\
\text { emergency, after clearly stated in the record, } \\
\text { the said rule may not be followed }\end{array}$ \\
\hline $\begin{array}{l}\text { 第 } 100 \text { 條之 } 3 \text { 第 } 1 \text { 項 } \\
\text { 司法警察官或司法警察詢問犯罪嫌疑人, } \\
\text { 不得於夜間行之。但有左列情形之一者, } \\
\text { 不在此限: } \\
\text { 一、經受詢問人明示同意者。 } \\
\text { 二、於夜間經拘提或逮捕到場而查驗其人 } \\
\text { 有無錯誤者。 } \\
\text { 三、經檢察官或法官許可者。 } \\
\text { 四、有急迫之情形者。 }\end{array}$ & $\begin{array}{l}\text { Art. } 100-3 \text { para. } 1 \\
\text { The interrogation of criminal suspects by } \\
\text { judicial police officer or judicial policeman } \\
\text { shall not proceed at night, except for the } \\
\text { following circumstances: } \\
\text { (1) express consent by the person being } \\
\text { interrogated; } \\
\text { (2) identity check of the person arrested with } \\
\text { or without a warrant at night; }\end{array}$ \\
\hline
\end{tabular}


(continued)

\begin{tabular}{l} 
Chinese \\
\hline \\
第 154 條第 1 項 \\
被告未經審判證明有罪確定前, 推定其爲 \\
無罪。
\end{tabular}

第 156 條第 1 項

被告之自白, 非出於強暴、脅迫、利誘、 詐欺、疲勞訊問、違法羈押或其他不正之 方法, 且與事實相符者, 得爲證據。

English

(3) permission by a public prosecutor or judge; or

(4) in case of emergency

Art. 154 para. 1

Prior to a final conviction through trial, an accused is presumed to be innocent

Art. 156 para. 1

Confession of an accused not extracted by violence, threat, inducement, fraud, exhausting interrogation, unlawful detention or other improper means and consistent with facts may be admitted as evidence

第 156 條第 3 項

被告陳述其自白係出於不正之方法者, 應 先於其他事證而爲調查。該自白如係經檢 察官提出者, 法院應命檢察官就自白之出 於自由意志, 指出證明之方法。

Art. 156 para. 3

If the accused states that his confession was extracted by improper means, his confession shall be investigated prior to investigating other evidences; if the said confession is presented by the public prosecutor, the court shall order the public prosecutor to indicate the method to prove that the confession is obtained under the free will of the accused

第 158 條之 2

Art. 158-2

I. 違背第 93 條之 1 第 2 項、第 100 條之 3

I. Any confession or other unfavorable 第 1 項之規定, 所取得被告或犯罪嫌疑人 之自白及其他不利之陳述, 不得作爲證 據。但經證明其違背非出於惡意, 且該自 白或陳述係出於自由意志者, 不在此限。 II. 檢察事務官、司法警察官或司法警察詢 問受拘提、逮捕之被告或犯罪嫌疑人時, 違反第 95 第 2 款、第 3 款之規定者, 準用 前項規定。 statements obtained from the accused or suspect in violation of the provisions of section II of Article 93-1 or section I of Article 100-3 shall not be admitted as evidence, provided that if lack of bad faith in such violation and the voluntariness of the confession or statement has been proven, the preceding section shall not apply

II. The provision of the preceding section shall apply mutatis mutandis to the case where the public prosecuting affairs official, judicial police officer, or judicial policeman violates the provisions of Items II and III of Article 95 in interrogating an accused or suspect arrested with or without a warrant

第 158 條之 4

除法律另有規定外, 實施刑事訴訟程序之 公務員因違背法定程序取得之證據, 其有 無證據能力之認定, 應審酌人權保障及公 共利盆之均衡維護。
Art. 158-4

The admissibility of the evidence, obtained in violation of the procedure prescribed by the law by an official in execution of criminal procedure, shall be determined by balancing the protection of human rights and the preservation of public interests, unless otherwise provided by law 
(continued)

\begin{tabular}{l} 
Chinese \\
\hline 第 163 條第 2 項 \\
法院絾發見真實, 得依職權調查證據。但 \\
於公平正莪之維護或對被告之利盆有重大 \\
關係事項, 法院應依職權調查之。
\end{tabular}

第 228 條第 1 項

檢察官因告訴、告發、自首或其他情事知 有犯罪嫌疑者, 應即開始偵查。

English

Art. 163 para. 2

The court may, for the purpose of discovering the truth, ex officio investigating evidence; in case for the purpose of maintaining justice or discovering facts that are critical to the interest of the accused, the court shall ex officio investigate evidence

Art. 228 para. 1

If a public prosecutor, because of complaint, report, voluntary surrender, or other reason, knows there is a suspicion of an offense having been committed, he shall immediately begin an investigation

第 230 條第 2 項

前項司法警察官知有犯罪嫌疑者, 應即開 始調查, 並將調查之情形報告該管檢察官 及前條之司法警察官。

Art. 230 para. 2

The judicial police officer specified in the preceding section who suspects that an offense has been committed shall initiate an investigation immediately and report the results thereof to the competent public prosecutor and the judicial police officer referred to in the preceding article

\section{第 231 條第 2 項 \\ 司法警察知有犯罪嫌疑者, 應即開始調查, 並將調查之情形報告該管檢察官及司法警 察官。}

Art. 231 para. 2

A judicial policeman who suspects that an offense has been committed shall initiate an investigation immediately and report the results thereof to the competent public prosecutor and judicial police officer

\section{第 245 條第 1 項}

偵查, 不公開之。

\section{第 245 條第 3 項}

檢察官、檢察事務官、司法警察官、司法 警察、讋護人、告訴代理人或其他於偵查 程序依法執行職務之人員, 除依法令或爲 維護公共利㿽或保護合法權望有必要者 外, 偵查中因執行職務知悉之事項, 員 敬啓

不得公開或揭露予執行法定職務必要範圍 以外之人員
Art. 245 para. 1

An investigation shall not be public

Art. 245 para. 3

The public prosecutor, public prosecution affairs official, judicial police officer or any other person performing their legally mandated duty during an investigation shall not in any way disclose the information acquired in their conduct of the investigation, unless otherwise permitted by law, or if necessary for the protection of public or legal interests

\section{Criminal Code (CCRC: 刑法)}

\begin{tabular}{l|l}
\hline Chinese & English \\
\hline 第 57 條第 10 款 & $\begin{array}{l}\text { Art. } 57 \text { clause } 10 \\
\text { Sentencing shall base on the liability of the } \\
\text { offender and take into account all the }\end{array}$ \\
\hline
\end{tabular}


(continued)

\begin{tabular}{|c|c|}
\hline Chinese & English \\
\hline $\begin{array}{l}\text { 科刑時應以行爲人之責任爲基礎,並審酌 } \\
\text { 一切情狀, 尤應注意下列事項, 爲科刑輕重 } \\
\text { 之標準: } \\
\text { 十、犯罪後之態度。 }\end{array}$ & $\begin{array}{l}\text { circumstances, and special attention shall be } \\
\text { given to the following items: } \\
\text { (10) The offender's attitude after committing } \\
\text { the offense }\end{array}$ \\
\hline $\begin{array}{l}\text { 第 } 125 \text { 條第 } 1 \text { 項 } \\
\text { 有追訴或處罰犯罪職務之公務員, 爲左列 } \\
\text { 行爲之一者, 處一年以上七年以下有期徒 } \\
\text { 刑: } \\
\text { 一、濫用職權爲逮捕或羈押者。 } \\
\text { 三、意圖取供而施強暴脅迫者。 } \\
\text { 三、明知爲無罪之人, 而使其受追訴或處 } \\
\text { 罰, 或明知爲有罪之人, 而無故不使其受追 } \\
\text { 訴或處罰者。 }\end{array}$ & $\begin{array}{l}\text { Art. } 125 \text { para. } 1 \\
\text { A public official charged with the duty of } \\
\text { investigation or bringing offenders to justice } \\
\text { who commits one of the following offenses } \\
\text { shall be sentenced to imprisonment for not } \\
\text { less than one year but not more than seven } \\
\text { years: } \\
\text { (1) Abusing his authority in arresting or } \\
\text { detaining a person } \\
\text { (2) Using threat or violence with purpose to } \\
\text { extract confession } \\
\text { (3) Knowingly causing an innocent person to } \\
\text { be prosecuted or punished or causing a guilty } \\
\text { person not be prosecuted or punished }\end{array}$ \\
\hline
\end{tabular}

\section{Constitution (CRC: 憲法)}

\begin{tabular}{l|l}
\hline Chinese & English \\
\hline 第 8 條第 2 項 & Art. 8 para. 2 \\
人民因犯罪嫌疑被逮捕拘禁時, 其逮捕拘 & When a person is arrested or detained on \\
禁機關應將逮捕拘禁原因, 以書面知本 & suspicion of having committed a crime, the \\
人及其本人指定之親友, 並至遲於 24 小時 & organ making the arrest or detention shall in \\
內移送該管法院審問。本人或他人亦得聲 & writing inform the said person, and his \\
請該管法院, 於 24 小時內向逮捕之機關提 & $\begin{array}{l}\text { designated relative or friend, of the grounds } \\
\text { 審。 }\end{array}$ \\
& $\begin{array}{l}\text { for his arrest or detention, and shall, within } 24 \\
\text { hours, turn him over to a competent court for } \\
\text { trial. The said person, or any other person, } \\
\text { may petition the competent court that a writ } \\
\text { be served within 24 hours on the organ } \\
\text { making the arrest for the surrender of the said } \\
\text { person for trial }\end{array}$ \\
\hline
\end{tabular}

IV. Communication Security and Surveillance Act (CSSA: 通訊保障及監察 法)

\begin{tabular}{l|l}
\hline Chinese & English \\
\hline 第 18 條第 3 項 & Art. 18-1 para. 3 \\
違反第 5 條、第 6 條或第7條規定進行監 & $\begin{array}{l}\text { Any content acquired through interception } \\
\text { that is in violation of Communication }\end{array}$ \\
聽行爲所取得之內容或所衍生之證據, 於 & $\begin{array}{l}\text { Security and Surveillance Act or any } \\
\text { 司法偵查、審判或其他程序中, 均不得採 }\end{array}$ \\
\hline
\end{tabular}


(continued)

\begin{tabular}{l|l}
\hline Chinese & English \\
\hline 爲證據或其他用途, 並依第 17 條第 2 項規 & $\begin{array}{l}\text { evidence deriving therefrom shall not be used } \\
\text { as evidence or used for any other purpose in } \\
\text { 定予以銷㞶。 }\end{array}$ \\
$\begin{array}{l}\text { any judicial investigation, judgment or other } \\
\text { proceeding }\end{array}$ \\
\hline
\end{tabular}

\section{Act to Implement the International Covenant on Civil and Political Rights and the International Covenant on Economic, Social and Cultural Rights (公民與政治權利國際公約及經濟社會文化權利國際公約施行法)}

\begin{tabular}{|c|c|}
\hline Chinese & English \\
\hline $\begin{array}{l}\text { 第 } 4 \text { 條 } \\
\text { 各級政府機關行使其職權, 應符合兩公約 } \\
\text { 有關人權保障之規定, 避免侵害人權, 保護 } \\
\text { 人民不受他人侵害, 並應積極促進各項人 } \\
\text { 權之實現。 }\end{array}$ & $\begin{array}{l}\text { Art. } 4 \\
\text { Whenever exercise their functions all levels } \\
\text { of governmental institutions and agencies } \\
\text { should confirm to human rights protection } \\
\text { provisions in the two Covenants; avoid } \\
\text { violating human rights; protect the people } \\
\text { from infringement by others; positively } \\
\text { promote realization of human rights }\end{array}$ \\
\hline
\end{tabular}

\section{References}

林鈺雄 (LIN Yu-Hsiung): 刑事訴訟法上冊 (Criminal Procedure Law (I)) $7^{\text {nd }}$ edition, Taipei 2013. [LIN Yu-Hsiung, 2013 (I)].

林鈺雄 (LIN Yu-Hsiung): 刑事訴訟法下冊 (Criminal Procedure Law (II)) $7^{\text {nd }}$ edition, Taipei 2013. [LIN Yu-Hsiung, 2013 (II)].

朱石炎 (ZHU Shi-Yan): 刑事訴訟法論 (Criminal Procedure) $5^{\text {nd }}$ edition, Taipei 2015. [ZHU Shi-Yan, 2015].

CHEN Yu-Jie (陳玉潔), 'One Problem, Two Paths: A Taiwanese Perspective on the Exclusionary Rule in China', (2011) 43 Journal of International Law and Politics NYU, 713-28. [CHEN Yu-Jie, 2011].

楊雲驊 (YANG Yun-Hua): 失衡的天平一評新修正通訊保障及監察法第18條之1 (An unbalanced balance - Comment on new Art. 18-1 of the Communication Security and Surveillance Act), 2014-7 檢察新論 (Taiwan Prosecutor Review), 3-24. [YANG Yun-Hua, 2014-7].

WANG Jaw-Perng (王兆鵬), 'The Evolution and Revolution of Taiwan's Criminal Justice', (2011) 3 Taiwan in Comparative Perspective, 8-29. [WANG Jaw-Perng, 2011].

Yu-Hsiung Lin is a professor of law at National Taiwan University, where he teaches criminal law and criminal procedure. He holds a Ph.D. from University of Munich (Germany) based on his thesis "Richtervorbehalt und Rechtsschutz gegen strafprozessuale Grundrechtseingriffe", which addresses remedies for court-ordered and non-court-ordered violations of constitutional rights in the criminal procedure. His main research interests lie in the field of criminal procedure and human rights law. This includes analyzes especially evidence, coercive measures and the human rights 
standards applied with a comparative view. He has published textbooks of criminal law and criminal procedure and edited several books on the issue of transnational judicial practice, including four volumes of essays published in 2007-2012 deal with ECHR cases suitable to providing guidance for future practice of Taiwan.

Shih-Fan Wang holds Ph.D. from University of Munich (Germany) and LL.M. from National Chengchi University (Taiwan). His research include comparative criminal procedure law and european and international criminal law. He teaches criminal procedure law and european and international criminal law at the National Taipei University, Taiwan.

Chung-Yen Chen is a lawer and also a Ph.D. candidate at the University of Tübingen (Germany) and hold an LL.M. from Fu Jen Catholic University (Taiwan). He used to serve as the prosecutor of the Taipei District Prosecutors Office. His research includes criminal law, criminal procedure law and criminal enforcement law, and mainly engaged in such cases. He also teaches criminal law at the National Tsing Hua University in Taiwan.

Tsai-Chen Tsai holds her Master degree from Finance college of Management in National Taiwan University. The topic of her Master thesis is empirical research of sentencing in respect of homicide. She served as a criminal division judge in the Supreme Court (1995-2014). After that, she became the director of Criminal Department of Judicial Yuan, R.O.C. (2014-2016). During her tenure, she was in charge of drafting and amending the criminal procedure law and criminal law, which is also related to her research topics. And recently, her researches are focusing on the evidence rules and standards of proof in criminal proceedings.

Chiou-Ming Tsai Director General, Department of International and Cross-Strait Legal Affair, Ministry of Justice, Taiwan. He had been working as prosecutor in Taiwan for more than 26 years before he was appointed as the Department head. As an amateur scholar, his interests of research range from intellectual property right, criminal evidence and comparative study of criminal procedure, to asset recovery, and international judicial cooperation in criminal matters.

Open Access This chapter is licensed under the terms of the Creative Commons Attribution 4.0 International License (http://creativecommons.org/licenses/by/4.0/), which permits use, sharing, adaptation, distribution and reproduction in any medium or format, as long as you give appropriate credit to the original author(s) and the source, provide a link to the Creative Commons license and indicate if changes were made.

The images or other third party material in this chapter are included in the chapter's Creative Commons license, unless indicated otherwise in a credit line to the material. If material is not included in the chapter's Creative Commons license and your intended use is not permitted by statutory regulation or exceeds the permitted use, you will need to obtain permission directly from the copyright holder.

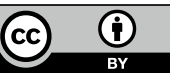

